\title{
Drawer Compacted Sand Filter: A new and innovative method for on-site greywater treatment
}

\author{
Almoayied Assayed, Jonathan Chenoweth, Steven Pedley \\ University of Surrey, Centre for Environmental Strategy GU2 7XH UK
}

\begin{abstract}
In this paper, results of a new sand filter design were presented. The Drawer Compacted Sand Filter (DCSF) is a modified design for a sand filter in which the sand layer is broken down into several layers, each of which is $10 \mathrm{~cm}$ high and placed in a movable drawer separated by a $10 \mathrm{~cm}$ space. A lab-scale DCSF was designed and operated for 330 days fed by synthetic greywater. The response of drawer sand filters to variable hydraulic and organic loading rates in terms of $\mathrm{BOD}_{5}, \mathrm{COD}$, TSS, $\mathrm{pH}$, EC and E.coli reductions were evaluated. The Hydraulic Loading Rate (HLR) was studied by increasing it stepwise from 72 to $142 \mathrm{~L} \mathrm{~m}^{-2}$ day $^{-1}$ and Organic Loading Rate (OLR) was studied by increasing it from 24 to $30 \mathrm{~g} \mathrm{BOD}_{5} \mathrm{~m}^{-2}$ day $^{-1}$ while keeping the HLR constant at $142 \mathrm{~L} \mathrm{~m}^{-2}$ day $^{-1}$. Each loading regime was applied for 110 days. Results showed that DCSF was able to remove $>90 \%$ of organic matter and Total Suspended Solids for all doses. No significant difference was noticed in terms of overall filter efficiency between different loads for all parameters. Significant reduction in $\mathrm{BOD}_{5}$ and $\mathrm{COD}(\mathrm{P}<0.05)$ was noticed after water drained through the third drawer in all tested loads. The paper concludes that DCSF would be appropriate for use in dense urban areas as its footprint is small and is appropriate for a wide range of users because of its convenience and low maintenance requirements.
\end{abstract}

Key words: synthetic greywater, hydraulic load, organic load, permeability test, drawer compacted sand filter

\section{Introduction}

Greywater reuse is a sustainable and attractive option to cope with global water shortages. It can save $40-70 \%$ of freshwater by reusing it for toilet flushing and irrigation (Jamarah et al. 2008). However, studies have revealed clearly that reuse of greywater without any priortreatment would increase soil salinity and the concentration of Sodium in the soil profile which ultimately cause deterioration of the soil texture (Palmquist et al. 2005; Eriksson et al. 2002). Studies have also observed that high organic matter and surfactants concentration in raw greywater would cause hydrophobic soil phenomena (Dalahemeh et al. 2011). 
Based on Dalahmeh et al. (2012), Nolde E. (2005), Ghaitidak et al. (2013), Abu Ghunmi et al. (2011) and Domenech et al. (2010), appropriate greywater treatment option should fulfill the following criteria:

- Technically sound: efficient in organic matter, solids and bacterial removal. The treatment must be able to produce water quality which complies with the national or international standards for greywater reuse.

- Reliability: minimal break downs or down-time and does not produce offensive odours.

- Low land footprint: the treatment unit should not require a large land area.

- Minimal installation and maintenance requirements: the treatment should be userfriendly and the maintenance can be accomplished by the user after minimal training.

- Economically-feasible: the treatment should be cost effective. The pay-back period for the treatment unit should be reasonable.

- High potential for scaling up and being used successfully in other communities and countries.

- Environmental tolerance: the unit can work in different weather conditions (i.e. high capacity to tolerate unfavorable environmental conditions) and tolerate the fluctuations in chemical and biological components of greywater.

- Aesthetics: the unit should not be aesthetically problematic and have an acceptable appearance.

- Operational and hygienic safety: all components of the unit should be safe to handle, have low potential for mosquito and fly reproduction, and should not allow any direct human contact with the greywater.

- Socially-accepted: on-site greywater management is a critical issue that not only depends on the technical feasibility of the treatment system, but also depends on human issues such as public perceptions and their participation. The success or failure of any decentralized wastewater management program depends significantly on public involvement, acceptance and feelings of ownership

After critical reviewing for current greywater treatment options, it was found that none of them fully matched these criteria. Some of treatment units were found to be technically efficient but economically unfeasible such as the Membrane Biological Reactor and Rotating 
Biological Contactor (Nolde E. 1999; Abdel-Kader A. 2013) while others were efficient but not user-friendly such as the Sequencing Batch Reactor (Kraume et al. 2010; Lamine et al. 2007) and Electro coagulations (Pidou et al. 2008; Lin et al. 2005) due to the complexity of controlling the dose of dissolved oxygen and chemical coagulants. Up-flow Anaerobic Sludge Blanket (UASB) units were also tested for greywater and found to be ineffective in organic and pathogens removal (ElMitwally et al. 2007; Leal et al. 2011). Constructed wetlands have been used widely for greywater, but due to the high footprint required for installation (Dallas et al. 2004, Boufaroua et al. 2013) it is not seen as an appropriate option in crowded areas.

Intermittent Sand Filters have been used successfully in water and wastewater treatment for more than a century. They consist of a multi-layer series of beds filled with a particular medium, such as washed graded sands, gravel, crushed glass or peat (USEPA guidelines, 2002). The water percolates through the filtering media after being fed onto the upper surface of sand. The distribution of wastewater usually occurs via well-designed manifold lines placed over the upper sand surface. However, aerobic and anaerobic treatment process prevail in Intermittent Sand Filter i.e. a biofilm develops on the sand particles in the upper sand levels which, in turn, absorbs soluble organic matter as it percolates over the sand surface; and anaerobic bacteria develops in the lower sand layers, where the oxygen level is substantially lesser (Torrens et al., 2009; Leverenze et al., 2009, USEPA guidelines, 2002, Metcalf \& Eddy, 1991). Maintaining aerobic conditions in the sand filter is considered essential to achieving high treatment efficiency. Clogging problems (Chris et al. 2009), a large land footprint, emission of bad odors due to anaerobic conditions in the lower levels of the sand beds and excavation difficulties in some regions of the sand filter are the main problems associated with using the conventional design of intermittent sand filters (table 1).

Table 1: Design parameter for the conventional intermittent sand filter according to USEPA and Metcalf \&Eddy

\begin{tabular}{|c|c|c|c|}
\hline \multirow[t]{2}{*}{ Design parameter } & \multirow[t]{2}{*}{ unit } & \multicolumn{2}{|c|}{ Typical Design values } \\
\hline & & $\begin{array}{c}\text { Metcalf \& Eddy } \\
\text { (1991) }\end{array}$ & $\begin{array}{l}\text { USEPA guidelines } \\
\text { (2002) }\end{array}$ \\
\hline \multicolumn{4}{|l|}{ Filter medium } \\
\hline Material & & $\begin{array}{l}\text { Washed durable } \\
\text { granular material }\end{array}$ & $\begin{array}{l}\text { Durable, } \\
\text { sand/gravel with rounded }\end{array}$ \\
\hline
\end{tabular}




$\begin{array}{llll} & & & \text { grains } \\ \text { Effective size } & \mathrm{mm} & 0.25-0.5 & 0.25-1.00 \\ \text { Depth } & \mathrm{cm} & 45-90 & 60-90 \\ \text { Underdrain } & & & \\ \text { Type } & & \begin{array}{l}\text { Washed durable gravel } \\ \text { or crushed stone }\end{array} & \text { Washed durable gravel or } \\ \text { crushed stone }\end{array}$

The aim of this paper is to suggest and optimize a new method of greywater treatment. The Drawer Compacted Sand Filter (DCSF) is a modified design for a sand filter in which the sand layer is broken down into several layers, each of which is $10 \mathrm{~cm}$ high and placed in a movable drawer separated by a $10 \mathrm{~cm}$ space (figure 1-a). This unit is hypothesized to have three main features:

1. Aerobic treatment in all layers

Drawer Compacted Sand Filter (DCSF) through dividing the sand depth into several layers and allowing air space between layers would ease the diffusion of oxygen between different layers (Rodgers et al. 2004; Leverenze et al. 2009) so that the filter will function with fully aerobic conditions, thus enhancing the aerobic biological treatment of greywater. The choosing of 6 drawers with $10 \mathrm{~cm}$ of sand depth in each drawer was based on Metcalf \& Eddy (1991) who reported that $60 \mathrm{~cm}$ for the whole sand depth is required for a conventional intermittent sand filter.

\section{Clogging is no longer serious problem}

One of the most prominent problems in conventional sand filtration is what is known as surface clogging (Rodgers et al. 2004). Surface clogging is a consequence of a reduction of pore space by suspended and dissolved solids and a biomass buildup on the upper surface of the sand layer (Leverenze et al. 2009; Seigrist 1987). In the DCSF unit, it is hypothesizing 
that sliding out the drawer, mixing up the media and then keeping the drawer off-line for 2448 hours would restore the filtering media without stopping the whole system. This maintenance procedure is very convenient compared to the laborious procedure in a conventional intermittent sand filter where the whole filter must be stopped and the first 5-10 cm of a quite big surface area must be skimmed off (Assayed et al. 2010; Chris et al. 2009).

\section{Low land footprint}

The surface area of an intermittent sand filter is a function of the flow rate and the hydraulic and organic load of the influent (Abu Ghunmi et al. 2008). Based on the Metcalf \& Eddy design criteria (Table 1), using a conventional intermittent sand filter for treatment of 200 $\mathrm{L} /$ day with $350 \mathrm{mg} / \mathrm{BOD}_{5}$ requires $14 \mathrm{~m}^{2}$. This high requirement of land is not applicable in dense urban areas, where the houses are crowded together and land is expensive and not always available. Reducing the land required for a conventional intermittent sand filter can be seen an option to cope with crowded areas. However, this will significantly increase the number of clogging events and therefore require laborious maintenance more often. In contrast, the DCSF only requires $1 \mathrm{~m}^{2}$ of land area, which can be easily found in the backyard or on the rooftop of a house. In DCSF, the sand layers are placed in movable drawers that are easily to be removed and cleaned. Therefore, the DCSF combines convenient and easy maintenance together with a low land footprint.

This research paper seeks to answer two questions:

- How do variations in hydraulic loading affect the performance of a DCSF?

- How do variations in organic loading affect the overall performance of a DCSF?

These questions are answered through the construction and testing of a laboratory based DCSF which was used to treat synthetic greywater over three 110 day periods of operation (330 days as a whole).

\section{Material and Methods}

\subsection{Drawer Compacted Sand Filter Fabrication}

A DCSF unit for testing and optimizing the design under laboratory conditions was constructed. A metal framework of $80 \mathrm{~cm}$ x $80 \mathrm{~cm}$ x $160 \mathrm{~cm}$ was designed and fabricated in a metal workshop located in Amman, Jordan. Six PVC drawers with dimensions of $75 \mathrm{~cm} \times 75$ 
$\mathrm{cm} \times 14 \mathrm{~cm}$ were obtained and placed on the frame (Figure 1-a\&b). Each drawer-except the lowest drawer (number 6) - was perforated with holes of the dimensions and sizes listed in table 2 (Figure 1-b). A distribution manifold (Figure 1-c) was designed and placed over the top drawer and a submersible pump was used to pump synthetic greywater from a small storage tank placed next to the DCSF to this distribution manifold (Figure 1-d). This pump was controlled by digital timer to give 12 doses per day. Table 2 shows all design details of the laboratory DCSF.

Table 2: Design parameters of the laboratory DCSF.

\section{Dimension of each drawer $\quad 75 \mathrm{~cm} \mathrm{x} 75 \mathrm{~cm} \times 14 \mathrm{~cm}$}

\section{Filter medium:}

Drawer 1

Drawer 2

Drawer 3

Drawer 4

Drawer 5

Drawer 6

Depth of media

Perforation - for each drawerexcept the lowest one- (figure )

\section{c)}

Distribution system (figure 1-

\section{Hydraulic loading}

Organic loading

Dosing frequency

Dosing tank volume
Gravels; effective size $2.5 \mathrm{~mm}$

Silica; effective size $1.2 \mathrm{~mm}$

Silica; effective size $0.7 \mathrm{~mm}$

Silica; effective size $0.7 \mathrm{~mm}$

Silica; effective size $1.2 \mathrm{~mm}$ and $0.7 \mathrm{~mm}$.

Granular activated carbon

$10 \mathrm{~cm}$ (for each drawer)

Orifice size $=4 \mathrm{~mm}$

Orifice spacing $=10 \mathrm{~cm}$

Number of orifices $=36$

Orifice spacing $=10 \mathrm{~cm}$

Lateral spacing $=11 \mathrm{~cm}$

Variable $\mathrm{L} / \mathrm{m}^{2}$.day

Variable $\mathrm{mgBOD}_{5} / \mathrm{m}^{2} . \mathrm{d}$

8 times / day

$120 \mathrm{~L}$ 


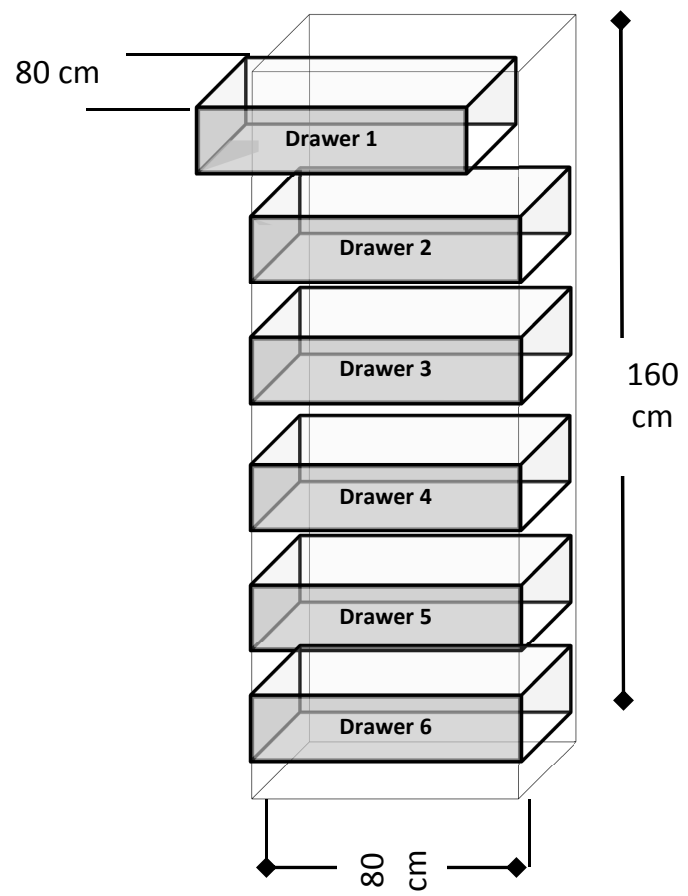

(a)

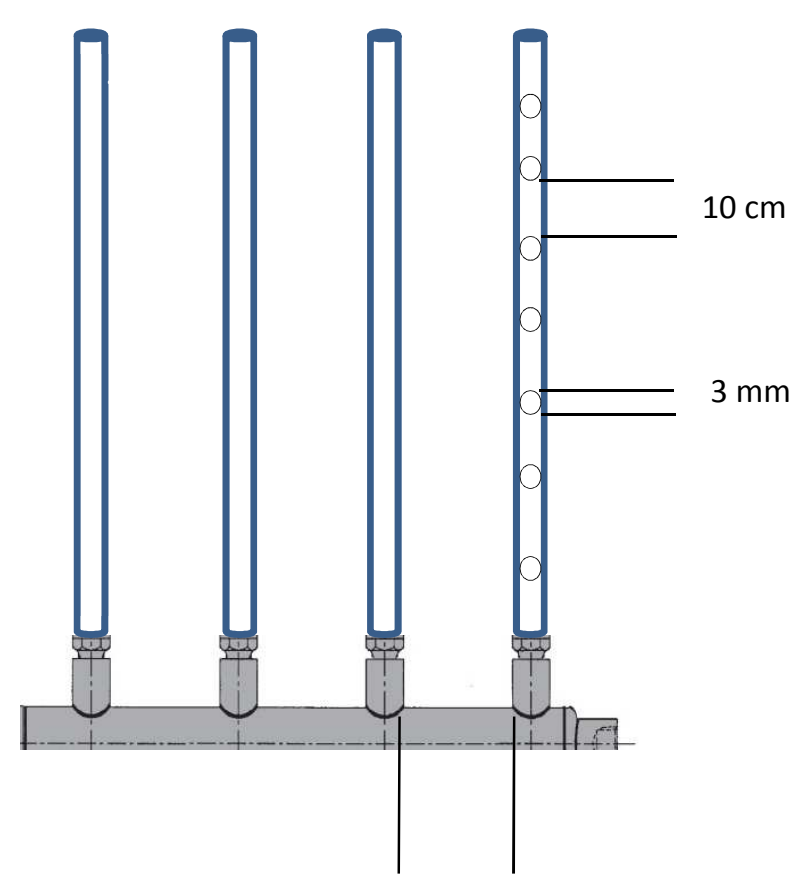

$11 \mathrm{~cm}$

(c)

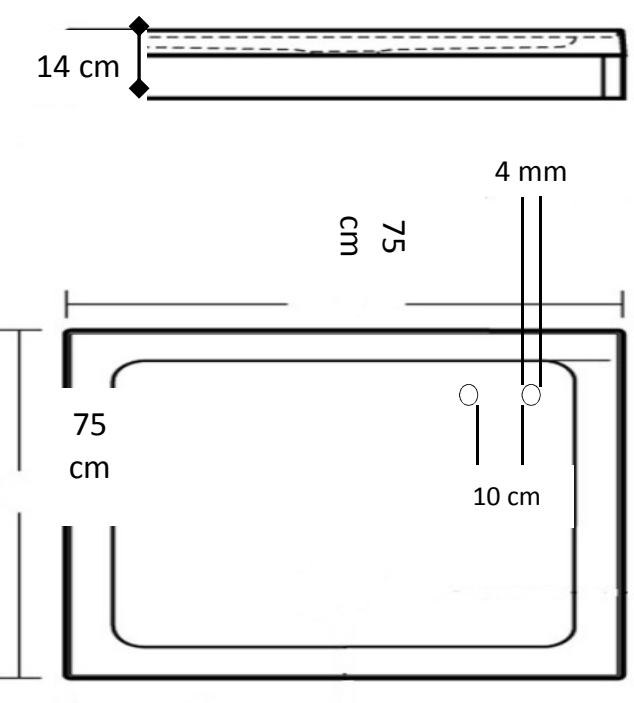

(b)

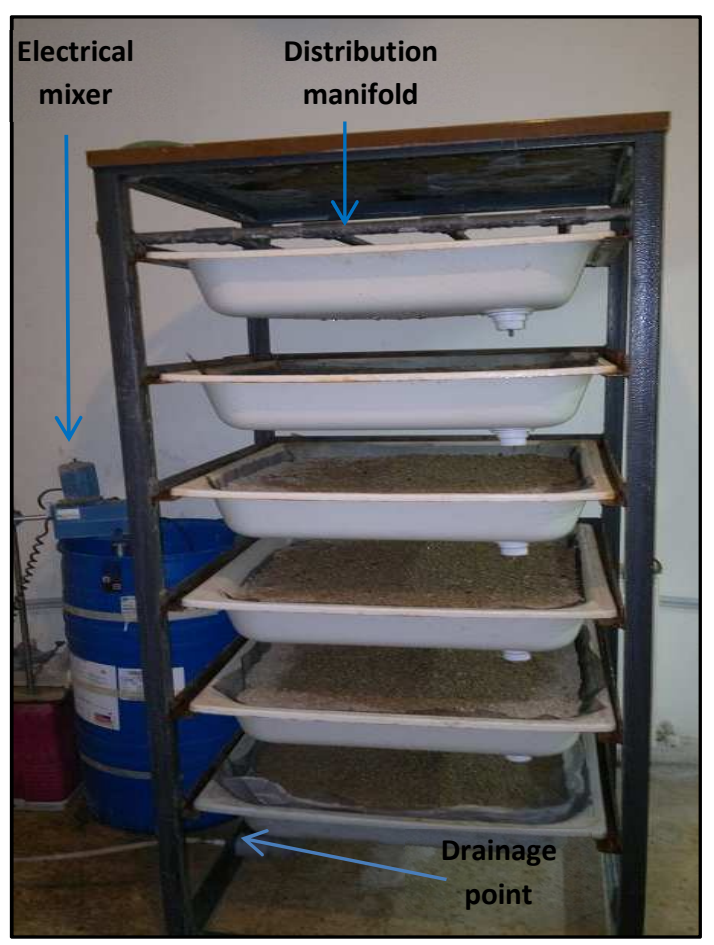

(d)

Figure 1: (a) Schematic diagram for metal frame (b) Dimensions of each drawer (c) Schematic diagram for distribution manifold (d) laboratory DCSF unit.

\subsection{Filter materials}


Small gravels and silica sand, of two different sizes, were used as treatment materials. These were obtained from local building materials suppliers. Small gravels were obtained from the Jordan River valley ${ }^{1}$, whereas the silica sand was obtained from the Naqab area in Jordan ${ }^{2}$. The gravel and sand were sieved according to the methodology suggested by ASTM (1998). The grain size distribution for gravels ranged from $(0.15-4.75) \mathrm{mm}$, the effective grain size $\left(\mathrm{D}_{10}\right)$ was $2.6 \mathrm{~mm}$. The grain size distribution for the two silica samples ranged from 0.4-2.36 and 0.15-2.36 and the effective size were $1.2 \mathrm{~mm}$ and $0.7 \mathrm{~mm}$, respectively. Silica of $1.2 \mathrm{~mm}$ effective size was given the code S1 and the other silica sample was given code S2. Each drawer was lined with $2 \mathrm{~mm}$ fiber mesh to prevent treatment material from slipping out through the holes in the drawers. Small gravels were placed in drawer number 1, S1 was placed in drawer 2, and S2 was put in drawers 3 and 4. Drawer number 5 was filled with $5 \mathrm{~cm}$ of $\mathrm{S} 1$ and $5 \mathrm{~cm}$ with $\mathrm{S} 2$ and $5 \mathrm{~cm}$ of granular activated carbon $\left(\mathrm{D}_{10}=2 \mathrm{~mm}\right)$ was used in drawer number 6 .

\subsection{Synthetic greywater}

Synthetic greywater was prepared so that the DCSF could be tested and optimized using greywater of consistent quality. The synthetic greywater was prepared by mixing $0.16 \mathrm{~g}$ of dishwashing solution (Golden, manufactured in Jordan), 0.16g hair shampoo (Sunsilk brand), $0.16 \mathrm{~g}$ washing powder (Persil brand), $0.1 \mathrm{~g}$ of maize oil, $4-5 \%(\mathrm{v} / \mathrm{v})$ of raw wastewater from the inlet pipe of Abu Nsair domestic wastewater treatment plant in North Amman to inoculate it with an indigenous bacterial flora and $1 \mathrm{~L}$ of tap water. Abu Nsair domestic wastewater treatment plant serves the upstream residential houses with average flow rate of $2600 \mathrm{~m}^{3} /$ day and average BOD $_{5} 552 \mathrm{mg} / \mathrm{l}$ (Ammary, 2007). This mixture gives a composition similar to that of natural greywater which excludes kitchen water, as reported in Eriksson et al. (2002) and Winword et al. (2008). An electronic mixer with $90 \mathrm{rpm}$ was used continuously to obtain a homogeneous solution. The synthetic greywater was prepared on daily basis and stored at room temperature.

\subsection{Experimental set-up}

The DCSF was operated for 330 days. For the first period of 110 days the unit was running under a flow rate of $40 \mathrm{~L} /$ day and organic matter content of $160 \mathrm{mg} / \mathrm{l} \mathrm{BOD}_{5}$ (hydraulic load $72 \mathrm{~L} \mathrm{~m}^{-2} \cdot \mathrm{d}^{-1}$ and organic load of 12 g BOD $\mathbf{~}_{5} \cdot \mathrm{m}^{-2} \mathbf{d}^{-1}$ ). For the second 110 day test period the

\footnotetext{
${ }^{1}$ Manaseer crusher company.

${ }^{2}$ The Middle East company for Silica.
} 
unit was running with a flow rate of $80 \mathrm{~L} /$ day and organic matter content of $160 \mathrm{mg} / \mathrm{BOD}_{5}$ (hydraulic load $142 \mathrm{~L} \cdot \mathrm{m}^{-2} \cdot \mathrm{d}^{-1}$ and organic load of $23 \mathrm{~g} \mathrm{BOD} \cdot \mathrm{m}^{-2} \mathrm{~d}^{-1}$ ), while for the final test period the unit was running with a flow rate of $80 \mathrm{~L} /$ day and organic matter content of

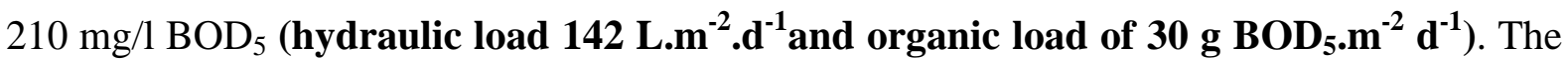
hydraulic behavior of the materials in drawers 1,2,3 and 4 were studied using soil permeability tests at the beginning and end of each load. It is worth mentioning here that after each experiment of 110 days, a new batch of treatment materials were installed in the drawers. Table (3) describes the operation variables for each load.

Table 3: The values of flow rate, hydraulic and organic loads in the three operation periods

\begin{tabular}{|c|c|c|c|c|c|c|c|}
\hline number & Period & $\begin{array}{l}\text { Flow rate } \\
\text { L/day }\end{array}$ & $\begin{array}{l}\mathrm{BOD}_{5} \\
\text { concentration } \\
\mathrm{mg} / \mathrm{l}\end{array}$ & $\begin{array}{l}\text { Hydraulic } \\
\text { load L.m } \\
{ }^{2} \cdot \mathrm{d}^{-1}\end{array}$ & $\begin{array}{l}\text { Organic load } \\
\mathrm{g} \mathrm{BOD}_{5} \cdot \mathrm{m}^{-2} \mathrm{~d}^{-1}\end{array}$ & $\begin{array}{l}\text { No. of } \\
\text { doses per } \\
\text { day }\end{array}$ & $\begin{array}{l}\text { Discharge per } \\
\text { dose (L) }\end{array}$ \\
\hline 1 & 110 & 40 & 160 & 72 & 12 & 8 & 5 \\
\hline 2 & 110 & 80 & 160 & 142 & 23 & 8 & 10 \\
\hline 3 & 110 & 80 & 210 & 142 & 30 & 8 & 10 \\
\hline
\end{tabular}

\subsection{Soil hydraulic conductivity}

Hydraulic conductivity is a measure of how easily water moves through the soil profile (Beach et al. 2005). It is a function of pressure, texture, the length of the soil column and the area through which the water moves. It was calculated by using equation 1 :

$$
K=\frac{V \cdot L}{T \cdot H \cdot A}
$$

Where $\mathrm{K}$ is the conductivity $(\mathrm{cm} / \mathrm{hr}), \mathrm{V}$ is the amount of water collected in the designated time, $\mathrm{T}$ is the time needed to collect the water, $\mathrm{H}$ is the height of water from the top of the core, $\mathrm{L}$ is the length of the soil core and A is the area of soil core.

\subsection{Sampling and Analysis}

Samples of influent and effluent greywater from the different loads were collected at regular intervals during the experimental period and analyzed for $\mathrm{BOD}_{5}, \mathrm{COD}$, TSS, E.coli, $\mathrm{pH}$ and EC. The tests were performed according to standard methods presented in table 4 . 
Table 4: Parameters analyzed, frequency of analysis and methods

\begin{tabular}{|c|c|c|c|}
\hline Parameter & $\begin{array}{l}\text { Frequency of testing for } \\
\text { each load }\end{array}$ & Method & $\begin{array}{l}\text { Reference no. in } \\
\text { Standard Method }\end{array}$ \\
\hline $\mathrm{BOD}_{5}$ & Weekly & 5-Day BOD Test & $5210 \mathrm{~A}$ \\
\hline COD & Monthly & $\begin{array}{l}\text { Open Reflux, } \\
\text { Titrimetric Method }\end{array}$ & $5220 \mathrm{C}$ \\
\hline TSS & Weekly & $\begin{array}{l}\text { Total Solids Dried At } \\
103-105^{\circ} \mathrm{C}\end{array}$ & $4500-\mathrm{H}^{+}$ \\
\hline $\mathrm{pH}$ & Weekly - biweekly & pH Method & 2520 \\
\hline $\mathrm{EC}$ & Weekly - biweekly & $\begin{array}{l}\text { Electrical } \\
\text { Conductivity Method }\end{array}$ & 2540 \\
\hline E.coli & $\begin{array}{l}\text { Twice during each } \\
\text { experiment }\end{array}$ & $\begin{array}{l}\text { Multiple-tube } \\
\text { fermentation } \\
\text { technique for } \\
\text { members of the } \\
\text { Coliforms Groups. }\end{array}$ & $9221 \mathrm{~F}$ \\
\hline
\end{tabular}

The efficiency of reduction for the various parameters analyzed was calculated using equation. 2:

$$
E=\frac{\text { Cout }-C \text { in }}{\text { Cout }} \times 100 \%
$$

Where $\mathrm{E}$ is the efficiency (percent), $\mathrm{C}$ in the influent concentration (milligram per liter) and $\mathrm{C}$ out the effluent concentration (milligram per liter).

\subsection{Mechanism of treatment in DCSF}

The greywater was pumped using a submersible pump and transferred via well-designed manifold lines placed over the upper surface of the sand layer of drawer number 1 . The water then percolates through the filtering media placed in drawer number 1 to drawer 2 and passively passes through the filtering media in all drawers. The dosing frequency is controlled by using a digital timer to supply 8 doses per day (dose/3 hours). The water, which comes out from the last drawer, is accumulated to be sampled and tested. 


\section{Results}

\subsection{Feed characteristics}

For experiments 1 and 2, the synthetic greywater contained $\mathrm{BOD}_{5}(\mathrm{n}=13) 160 \pm 80 \mathrm{mg} / \mathrm{l}$, TSS $(n=13) 66 \pm 3$, COD $(n=6) 304 \pm 66$. The proportion of raw wastewater inoculums was an estimated $4 \%$ to produce $10^{4}-10^{5} \mathrm{CFU} / 100 \mathrm{ml}$ of E.coli, which has been reported for the greywater in Jordan (Halalshe et al. 2007). For experiment number 3, the synthetic greywater contained BOD $_{5}(n=10) 210 \pm 70$, TSS $(n=10) 169 \pm 51$, COD $(n=6) 483 \pm 115$. The proportion of raw wastewater used for experiment number 3 was 5\%. Though the synthetic greywater was prepared on daily basis, fluctuation in organic and solids content was clearly noticed. This was attributed according to Dalahmeh et al. (2012) to fluctuation in water and ambient temperatures, quality of raw wastewater inoculums and mixing time. The $\mathrm{BOD}_{5} / \mathrm{COD}$ ratio ranged from $0.43-0.52$ which indicates that about half of organic load is bioavailable for degradation. This ratio is also similar to what has been reported by Halalsheh et al. (2007) and Assayed et al. (2010) for greywater in Jordan.

\subsection{Filter performance}

\subsubsection{Experiment number 1}

In all doses, Electrical Conductivity (EC) increased slightly in the treated greywater, whereas the $\mathrm{pH}$ values remained very similar to that of the influent. No significant variations were noticed in $\mathrm{pH}$ and EC between several drawers (Table 5). Calculating the efficiency for each drawer showed that $97 \%, 94 \%$, and $97 \%$ of $\mathrm{BOD}_{5}, \mathrm{COD}$, and TSS removal was obtained after the water passed through the first 3 drawers, while no significant reduction was noticed after passing through other drawers (Figure 2-a, b \&c). The faecal indictor bacteria i.e. E.coli, was reduced by $3 \operatorname{logs}$ leaving $2.2 \times 10^{3} \mathrm{CFU} / 100 \mathrm{ml}$ of E.coli in the treated greywater.

Table 5: Influent characteristics and treatment performance (mean \pm standard deviation) of the different drawers at $\mathrm{HL}=72 \mathrm{~L} \cdot \mathrm{m}^{-2} \cdot \mathrm{d}^{-1}$ and $\mathrm{OL}=12 \mathrm{~g} \mathrm{BOD}_{5} \mathrm{~m}^{-2} \mathrm{~d}^{-1}$

\begin{tabular}{|c|c|c|c|c|c|c|c|}
\hline \multirow[t]{2}{*}{ Parameter } & \multirow{2}{*}{$\begin{array}{l}\text { Concentration } \\
\text { in influent }{ }^{\mathrm{a}}\end{array}$} & \multicolumn{6}{|c|}{ Concentration reduction in effluent $^{b}$} \\
\hline & & Drawer 1 & Drawer 2 & Drawer 3 & Drawer 4 & Drawer 5 & Drawer 6 \\
\hline $\mathrm{pH}(\mathrm{SD})$ & $8.00 \pm 0.6$ & $7.65 \pm 0.25$ & $7.86 \pm 0.38$ & $7.79 \pm 0.21$ & $7.76 \pm 0.27$ & $8.00^{\mathrm{c}}$ & $7.8 \pm 0.13$ \\
\hline
\end{tabular}




\begin{tabular}{|c|c|c|c|c|c|c|c|}
\hline $\mathrm{EC}\left(\mu \mathrm{S} \mathrm{cm}{ }^{-2}\right)$ & $1419 \pm 260$ & $1703 \pm 413$ & $1605 \pm 386$ & $1775 \pm 445$ & $1353 \pm 26$ & 1389 & $1556 \pm 300$ \\
\hline $\mathrm{BOD}_{5}$ & $160 \pm 49$ & 109 & $22 \pm 7.0$ & $3.4 \pm 1.4$ & $5.0 \pm 4.0$ & $2.7 \pm 2.7$ & $1.8 \pm 1.4$ \\
\hline COD & $304 \pm 66$ & 223 & $44 \pm 15$ & $18 \pm 2$ & $19 \pm 5$ & $15 \pm 4$ & $7 \pm 2$ \\
\hline TSS & $104 \pm 37$ & 55 & $13 \pm 8.0$ & $3.5 \pm 2.0$ & $5.5 \pm 2.6$ & $3.3 \pm 1.7$ & $2.5 \pm 2.0$ \\
\hline $\begin{array}{l}\text { E.coli (CFU/100 } \\
\mathrm{ml})\end{array}$ & $4.3 \mathrm{E}+06$ & NA & NA & NA & NA & NA & $2.12 \mathrm{E}+03$ \\
\hline
\end{tabular}

${ }^{a}$ All units are in milligram per liter unless otherwise stated.

${ }^{\mathrm{b}}$ Percentage reduction is not valid for $\mathrm{pH}$ and EC. Concentrations measured in the effluent are shown in the table.

\subsubsection{Experiment number 2}

Likewise in the first experiment, no significant variations were noticed in $\mathrm{pH}$ and $\mathrm{EC}$ between influent and effluent between the different drawers; $\mathrm{pH}$ ranged from (7.6-7.85) and EC values fluctuated between $\left(1300-1390 \mu \mathrm{S} \mathrm{cm}^{-1}\right.$ ) for all doses (Table 6). About $91 \%$ of TSS removal was achieved after passing through drawer number 3 (Figure 2-b). However, $90 \%$ of $\mathrm{BOD}_{5}$ and $\mathrm{COD}$ removal was obtained only after the water had passed through all the drawers i.e. drawers 1- 6 (Figure 2- a \& c). E.coli also reduced 3 logs after the water had passed through all drawers leaving $3.4 \times 10^{3}$ in the treated greywater.

Table 6: Influent characteristics and treatment performance (mean \pm standard deviation) of the different drawers at $\mathrm{HL}=142 \mathrm{~L} \cdot \mathrm{m}^{-2} \cdot \mathrm{d}^{-1}$ and $\mathrm{OL}=23 \mathrm{~g} \mathrm{BOD} \mathrm{m}^{-2} \mathrm{~d}^{-1}$

\begin{tabular}{|c|c|c|c|c|c|c|c|}
\hline \multirow[t]{2}{*}{ Parameter } & \multirow{2}{*}{$\begin{array}{l}\text { Concentration } \\
\text { in influent }\end{array}$} & \multicolumn{6}{|c|}{ Concentration reduction in effluent } \\
\hline & & $\begin{array}{c}\text { Drawer } \\
1\end{array}$ & Drawer 2 & Drawer 3 & Drawer 4 & Drawer 5 & Drawer 6 \\
\hline $\mathrm{pH}(\mathrm{SD})$ & $7.70 \pm 0.035$ & $\begin{array}{c}7.56 \pm 0.0 \\
45\end{array}$ & $\begin{array}{c}7.75 \pm 0.1 \\
5\end{array}$ & $\begin{array}{c}7.80 \pm 00 . \\
10\end{array}$ & $\begin{array}{c}7.90 \pm 0.2 \\
7\end{array}$ & $\begin{array}{c}7.9 \pm 0.23 \\
5\end{array}$ & $\begin{array}{c}7.84 \pm 0.00 \\
5\end{array}$ \\
\hline $\mathrm{EC}\left(\mu \mathrm{S} \mathrm{cm}{ }^{-2}\right)$ & $1294 \pm 20$ & $1295 \pm 75$ & $1324 \pm 30$ & $1296 \pm 75$ & $1350 \pm 26$ & $1348 \pm 43$ & $1364 \pm 27$ \\
\hline $\mathrm{BOD}_{5}$ & $169 \pm 61$ & $72 \pm 29$ & $34 \pm 18$ & $26 \pm 24$ & $29 \pm 24$ & $11 \pm 9.0$ & $8.0 \pm 4.0$ \\
\hline COD & $333 \pm 1.0$ & $146 \pm 10$ & $128 \pm 38$ & $89 \pm 27$ & $66 \pm 23$ & $50 \pm 22$ & $30 \pm 17$ \\
\hline TSS & $77 \pm 3.0$ & $19 \pm 8.0$ & $11 \pm 3.0$ & $7.2 \pm 4.3$ & $\begin{array}{c}3.75 \pm 1.2 \\
5\end{array}$ & $5.0 \pm 2.90$ & $4.3 \pm 2.71$ \\
\hline $\begin{array}{l}\text { E.coli } \\
(\mathrm{CFU} / 100 \mathrm{ml})\end{array}$ & $4.3 \mathrm{E}+06$ & NA & NA & NA & NA & NA & $3.4 \mathrm{E}+03$ \\
\hline
\end{tabular}




\subsubsection{Experiment number 3}

No significant variations were noticed between influent and effluent in $\mathrm{pH}$ and EC as a result of the water passing through the drawers (Table 7). A $93 \%$ reduction of $\mathrm{BOD}_{5}$ and a $94 \%$ reduction of COD were achieved after the water had passed through the third drawer (Figure 2- a \& c). Likewise in the previous experiments, a 3 logs reduction in E.coli was achieved when the water passed from drawer number 6.

Table 7: Influent characteristics and treatment performance (mean \pm standard deviation) of the different drawers at $\mathrm{HL}=142 \mathrm{~L} \cdot \mathrm{m}^{-2} \cdot \mathrm{d}^{-1}$ and $\mathrm{OL}=30 \mathrm{~g} \mathrm{BOD} \mathrm{m}^{-2} \mathrm{~d}^{-1}$

\begin{tabular}{lccccccc}
\hline Parameter & $\begin{array}{l}\text { Concentration } \\
\text { in influent }\end{array}$ & \multicolumn{5}{c}{ Concentration reduction in effluent } \\
\cline { 3 - 7 } & & Drawer 1 & Drawer 2 & Drawer 3 & Drawer 4 & Drawer 5 & Drawer 6 \\
\hline $\mathrm{pH}(\mathrm{SD})$ & $7.73 \pm 0.11$ & $8.01 \pm 0.27$ & $7.4 \pm 0.01$ & $7.62 \pm 0.16$ & $7.65 \pm 0.15$ & $7.74 \pm 0.04$ & $7.73 \pm 0.26$ \\
$\mathrm{EC}\left(\mu \mathrm{S} \mathrm{cm}{ }^{-2}\right)$ & $1372 \pm 116$ & $1494 \pm 159$ & $1495 \pm 140$ & $1411 \pm 179$ & $1532 \pm 114$ & $1534 \pm 154$ & $1489 \pm 178$ \\
$\mathrm{BOD}_{5}$ & $208 \pm 70$ & $77 \pm 34$ & $36 \pm 9$ & $14 \pm 2$ & $7 \pm 2$ & $4.3 \pm 2.5$ & $4.8 \pm 1.1$ \\
$\mathrm{COD}$ & $438 \pm 115$ & $154 \pm 43$ & $46 \pm 10$ & $29 \pm 6$ & 13 & 4 & NA \\
TSS & $169 \pm 51$ & $54 \pm 18$ & $16 \pm 9$ & $7 \pm 4.5$ & $1.5 \pm 1.5$ & $2.8 \pm 2.7$ & $8 \pm 3$ \\
$\begin{array}{l}\text { E.coli }(\mathrm{CFU} / 100 \\
\mathrm{ml})\end{array}$ & $6.50 \mathrm{E}+05$ & $\mathrm{NA}$ & $\mathrm{NA}$ & $\mathrm{NA}$ & $\mathrm{NA}$ & $\mathrm{NA}$ & $8.0 \mathrm{E}+02$
\end{tabular}

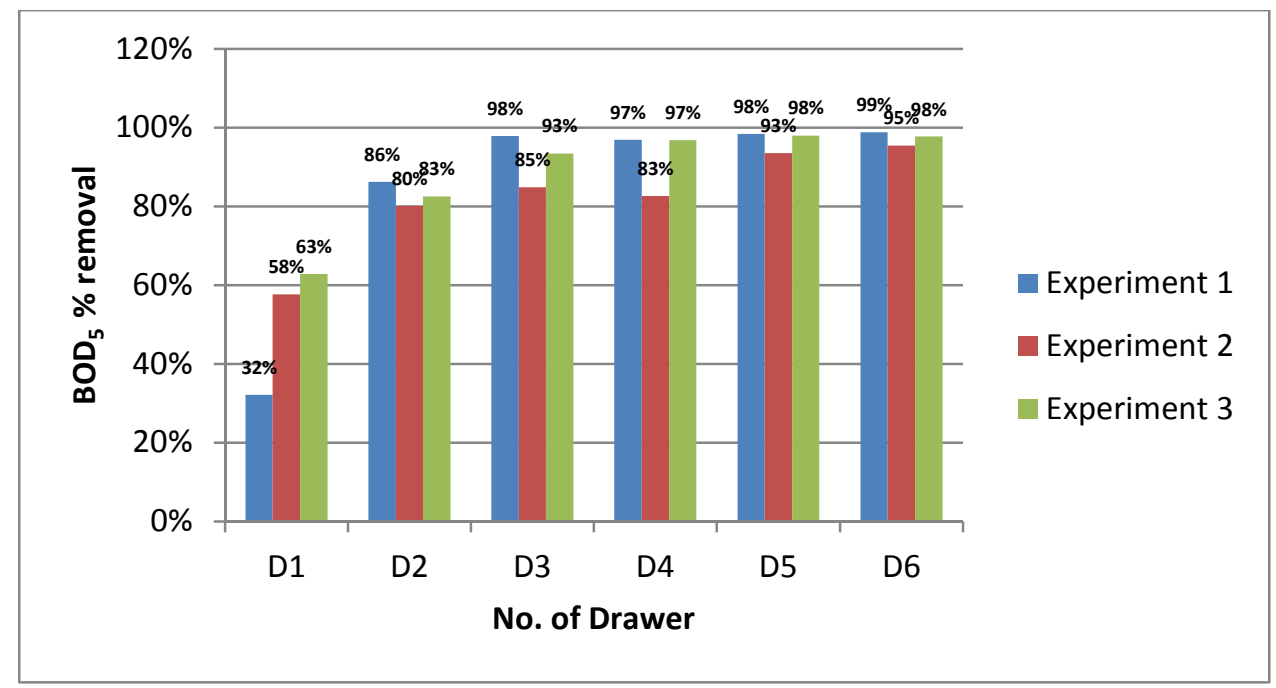


(a)

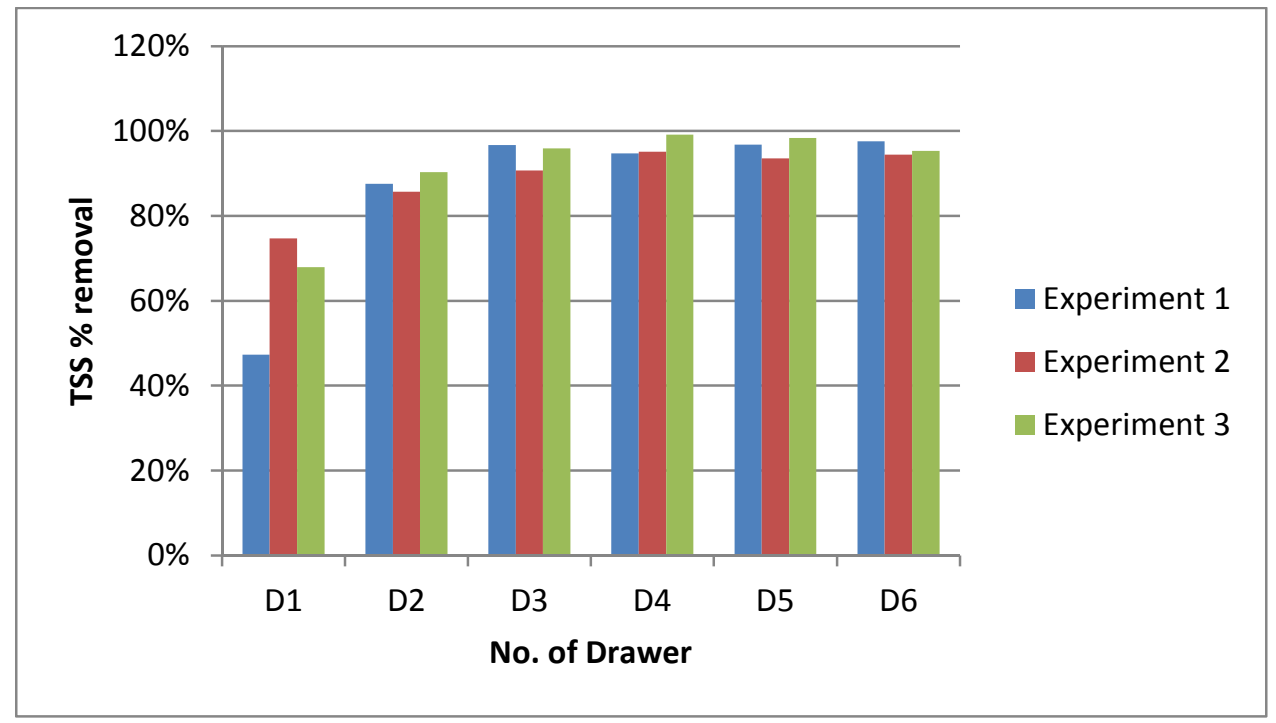

(b)

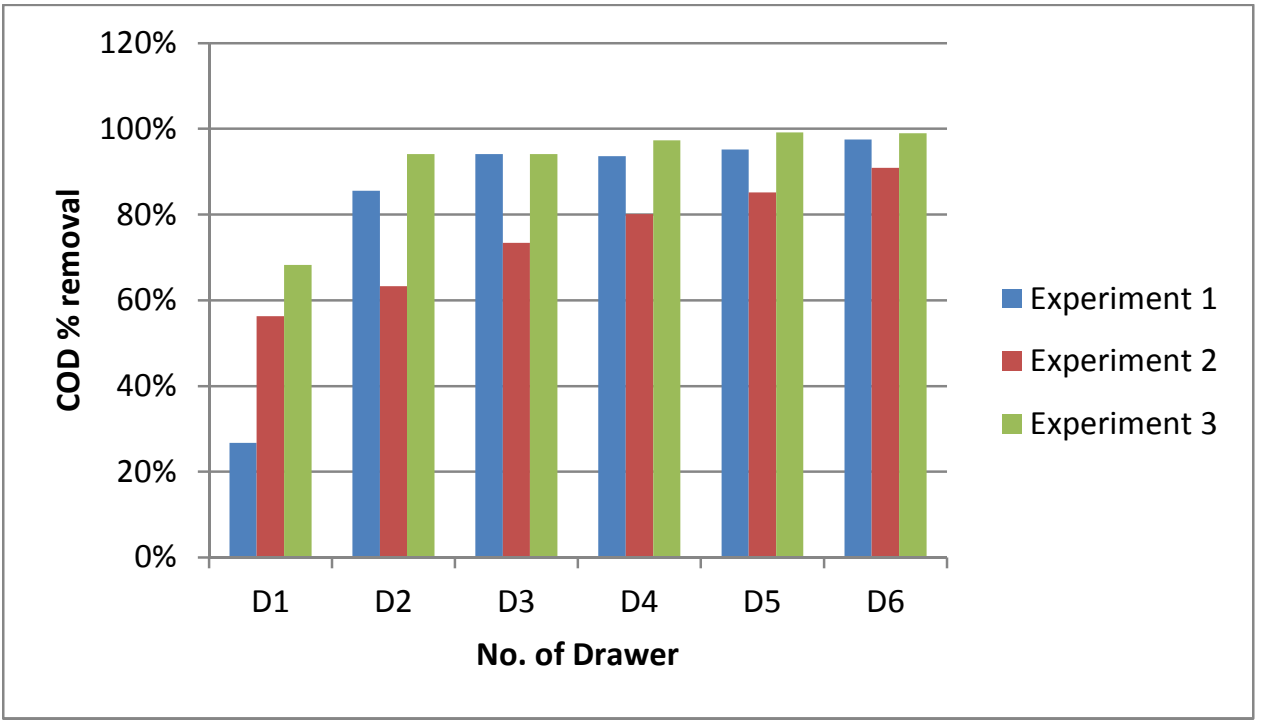

(c)

Figure 2: (a) BOD\% removal for the three experiments (b) TSS \% removal for the three experiments (c) COD \% removal for the three experiments.

\subsection{Sand hydraulic conductivity (permeability test)}

Hydraulic conductivity was measured for the sand in drawers 1, 2, 3 and 4. The test was conducted two times i.e. at the beginning and at the end of each experiment. As shown in figures $3,4 \& 5$ the ability of sand to convey water decreases in time due to biofilm growth and solids build up on the upper surface which leading to a decrease in free pore spaces. 
There was no clear trend in hydraulic conductivity fluctuation between the three experiments. The slight difference in hydraulic conductivity between drawers in the three experiments can be attributed to the changes in greywater contents in terms of $\mathrm{BOD}_{5}$ and TSS concentration. Using chemical tracers is recommended for further studies to investigate the hydraulic behaviors of sand in drawers.

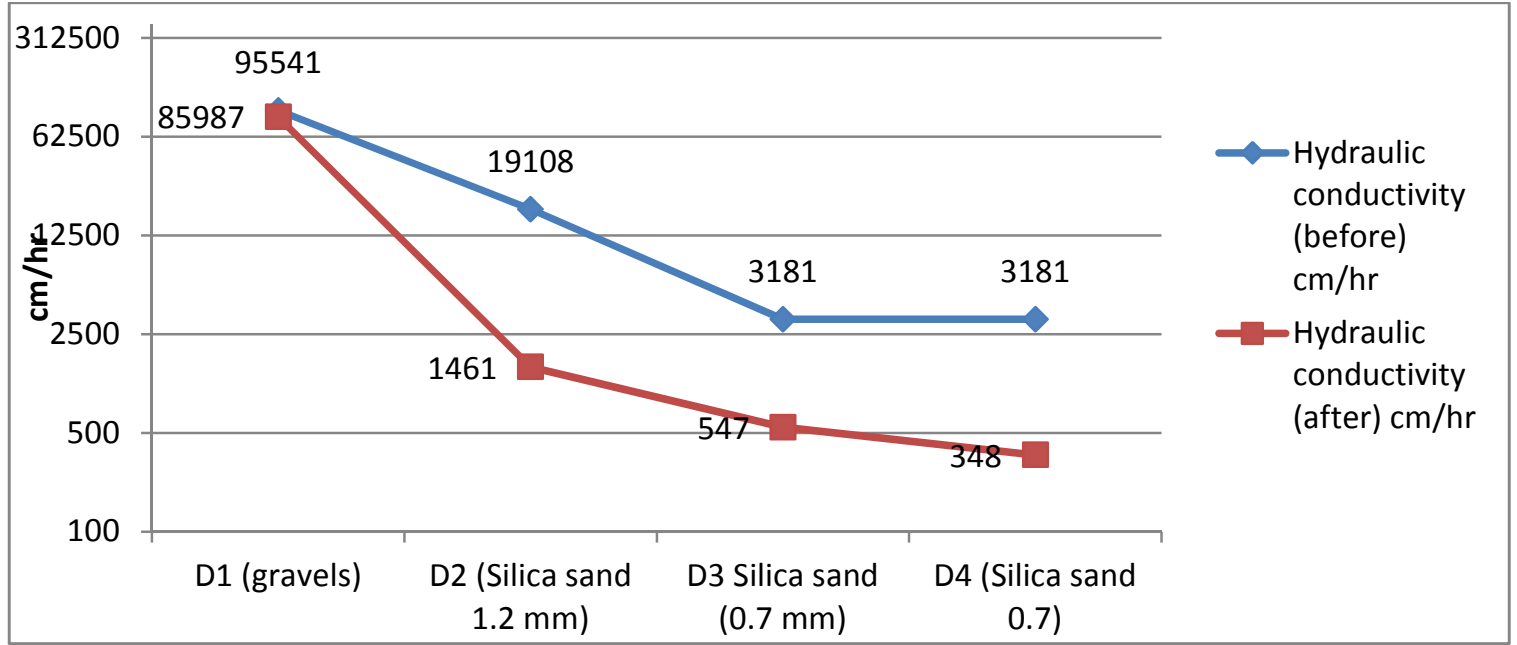

Figure 3: Variation in soil hydraulic conductivity before and after greywater application for the experiment no. 1 .

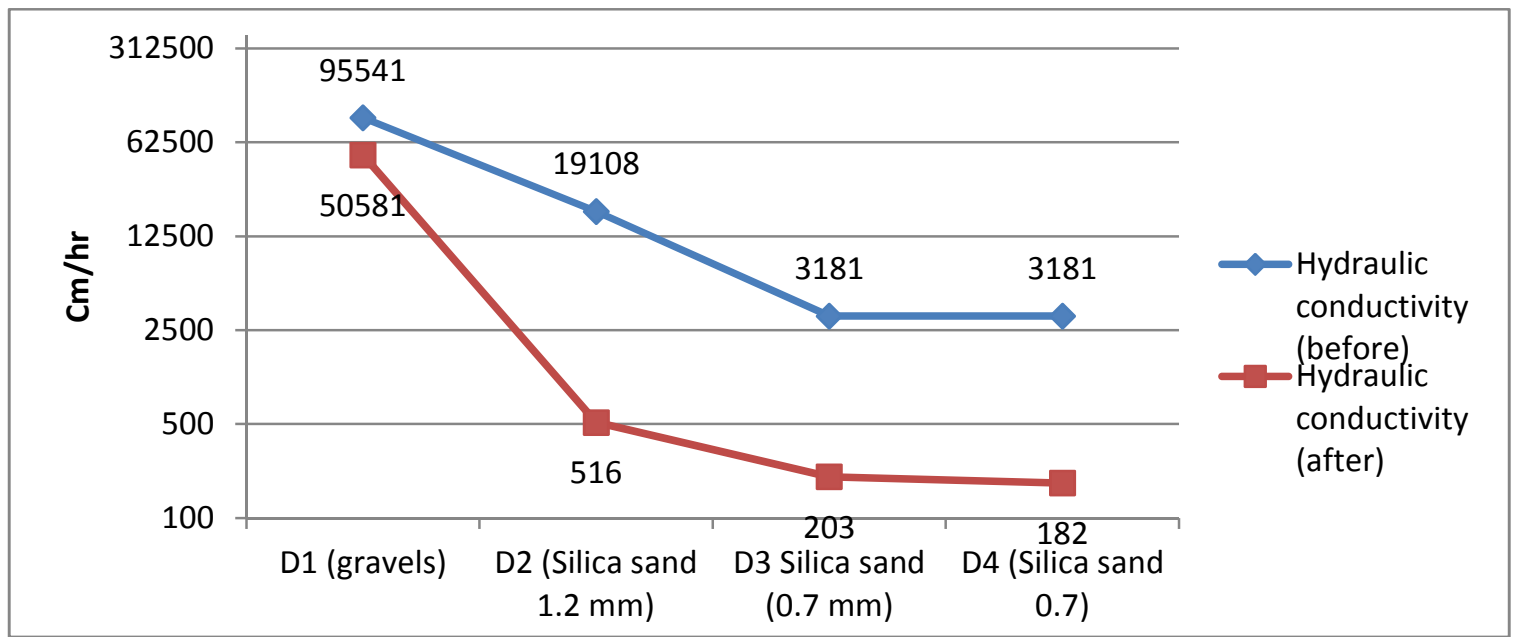

Figure 4: Variation in soil hydraulic conductivity before and after greywater application for the experiment no. 2. 


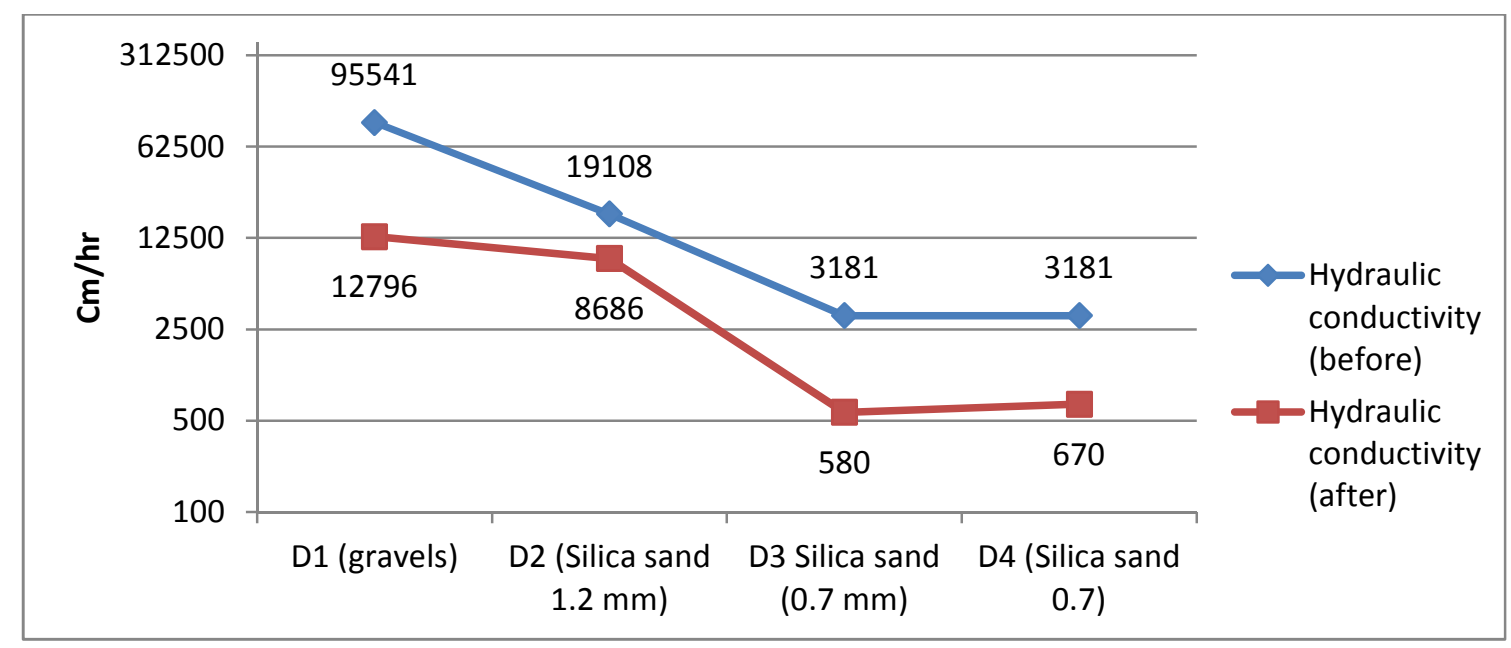

Figure 5: Variation in soil hydraulic conductivity before and after greywater application for the experiment no. 3 .

\section{Discussion}

Sand filtration is probably the most widely used method for water treatment, particularly for greywater, but the problems of clogging and high land footprint, in addition to anaerobic conditions in the lower parts of the filter bed are considered prominent challenges for this treatment method. In the present study, a new design of sand filtration was suggested and tested under laboratory conditions. The new design of sand filter was based on the idea of placing filtering media in movable drawers thus enabling oxygen movement and easing maintenance procedures without sacrificing treatment efficiency.

\subsection{Filter performance}

\subsubsection{Variations of hydraulic loading vs. filter performance}

Two different hydraulic loads (Experiments 1 and 2) were used to find out the impacts of various hydraulic loads on the overall filter performance while $\mathrm{BOD}_{5}$ concentration was kept constant for both experiments. However, given that organic load is directly correlated with hydraulic load (Abu ghunmi et al. 2008), the organic load for the second experiment was essentially doubled. Nonetheless, the rest of design parameters shown in table 2 were kept constant during testing the two loads. Each load was tested for 110 days and fed by synthetic greywater on a daily bases.

The ANOVA test was carried out to find out the statistically significant differences between different variables in the two experiments (Table $8 \& 9$ ). No significant differences in filter 
performance were noticed in either experiment $(\mathrm{P}>0.05)$. More than $90 \%$, of $\mathrm{BOD}_{5}, 95 \%$ of COD and $95 \%$ of TSS removal were achieved in the two experiments (i.e. 70 L.m $\mathrm{m}^{-2}$.day ${ }^{-1}$ and $142 \mathrm{~L} . \mathrm{m}^{-2}$. day $^{-1}$ ) when water was drained from drawer 1 to drawer 6, leaving less than $5 \mathrm{mg} / \mathrm{l}$ of $\mathrm{BOD}_{5} ; 10 \mathrm{mg} / \mathrm{l}$ of COD and $5 \mathrm{mg} / \mathrm{l}$ of TSS in the effluent. This was in agreement with sand filter performance for greywater treatment in different areas using a conventional design (Table 1). Assayed (2010) reported 90\%, 95\% and 95\% of $\mathrm{BOD}_{5}, \mathrm{COD}$ and TSS removal from greywater when using intermittent sand filters. Also, Tyagi et al. (2009) reported 85\% of $\mathrm{BOD}_{5}$ and $77 \%$ of COD and $89 \%$ removal of TSS when using sand filtration for treatment of UASB effluent.

For both experiments 1 and 2, significant pollutant removal was noticed after the water passed from the drawers 1,2 and $3(\mathrm{P}<0.05)$ (Table $8 \& 9)$. More than $85 \%$ of $\mathrm{BOD}_{5}$ and TSS removal was achieved after the water drained from drawer number 3. This finding was in agreement with what was concluded by Rodgers et al. 2004 who stated that the significant treatment of sand filtration occurs in the uppermost surface of the sand layers.

$\log _{10}$ removals of indicator bacteria i.e. E.coli with the two different hydraulic loads are slightly different to those reported previously for greywater treatment. Three logs of E.coli reduction were achieved for both hydraulic loads tested. This was not the case for Torrens et al. (2009) and Stevik et al. (1999) who found E.coli reduction is inversely correlated with hydraulic loads and directly related with the media depth. However, the constant reduction of E.coli in all loads might be attributed to the small dose size $(5-10 \mathrm{~L})$ which according to Stevik et al. (1999) is an important factor for bacterial removal rather than the daily dosing rate. Further investigation is required to find out more on the E.coli and other pathogens removal in the drawer sand filter.

\subsubsection{Variations of organic loading vs. filter performance}

The drawer compacted filter was subject to two different organic loads i.e. $20 \mathrm{~g} \mathrm{BOD} 5 \cdot \mathrm{m}^{-2} \cdot \mathrm{d}^{-1}$ and $30 \mathrm{~g} \mathrm{BOD} 5 \cdot \mathrm{m}^{-2} \cdot \mathrm{d}^{-1}$. The hydraulic load was kept at $142 \mathrm{~L} \cdot \mathrm{m}^{-2} \cdot \mathrm{d}^{-1}$ and each experiment lasted 110 days.

Likewise in the previous experiments, no significant variations in pollutant reduction occurred when testing the two loads $(\mathrm{P}>0.05)$. The reduction in $\mathrm{BOD}_{5}, \mathrm{COD}$, and TSS was more than $90 \%$ for two loads after water emerged from the filter. However, more than $85 \%$ of pollutants were removed after the water passed from drawer number three $(\mathrm{P}<0.05)$. As 
noticed in the previous experiments, three logs in E.coli reduction were achieved when the water passed through all drawers regardless of the variations in organic loads, which was expected, as the microbial load was not significantly changed across various organic and hydraulic loads.

Table 8: The $\mathrm{BOD}_{5}$ correlations between drawers for all experiments.

\begin{tabular}{|c|c|c|c|c|c|c|c|c|}
\hline \multicolumn{9}{|c|}{ Correlations } \\
\hline & & Inf. & D1 & D2 & D3 & D4 & D5 & Eff. \\
\hline \multirow{3}{*}{ Inf. } & Pearson Correlation & 1 & .366 & .328 & .319 & .203 & .083 & .352 \\
\hline & Sig. ( P value) & & .298 & .232 & .312 & .548 & .798 & .198 \\
\hline & $\mathrm{N}$ & 17 & 10 & 15 & 12 & 11 & 12 & 15 \\
\hline \multirow[t]{3}{*}{ D1 } & Pearson Correlation & .366 & 1 & .234 & .492 & .390 & .356 & .227 \\
\hline & Sig. ( P value) & .298 & & .514 & .149 & .299 & .347 & .528 \\
\hline & $\mathrm{N}$ & 10 & 10 & 10 & 10 & 9 & 9 & 10 \\
\hline \multirow[t]{3}{*}{ D2 } & Pearson Correlation & .328 & .234 & 1 & $.763^{* *}$ & $.663^{*}$ & $.795^{* *}$ & $.759^{* * *}$ \\
\hline & Sig. ( P value) & .232 & .514 & & .004 & .026 & .002 & .002 \\
\hline & $\mathrm{N}$ & 15 & 10 & 15 & 12 & 11 & 12 & 14 \\
\hline \multirow[t]{3}{*}{ D3 } & Pearson Correlation & .319 & .492 & $.763^{* *}$ & 1 & $.942^{* *}$ & $.875^{* *}$ & $.911^{* * *}$ \\
\hline & Sig. ( P value) & .312 & .149 & .004 & & .000 & .000 & .000 \\
\hline & $\mathrm{N}$ & 12 & 10 & 12 & 12 & 11 & 11 & 12 \\
\hline \multirow[t]{3}{*}{ D4 } & Pearson Correlation & .203 & .390 & $.663^{*}$ & $.942^{* *}$ & 1 & $.796^{* *}$ & $.942^{* *}$ \\
\hline & Sig. ( P value) & .548 & .299 & .026 & .000 & & .003 & .000 \\
\hline & $\mathrm{N}$ & 11 & 9 & 11 & 11 & 11 & 11 & 11 \\
\hline \multirow[t]{3}{*}{ D5 } & Pearson Correlation & .083 & .356 & $.795^{* *}$ & $.875^{* *}$ & $.796^{* *}$ & 1 & $.781^{* *}$ \\
\hline & Sig. ( P value) & .798 & .347 & .002 & .000 & .003 & & .005 \\
\hline & $\mathrm{N}$ & 12 & 9 & 12 & 11 & 11 & 12 & 11 \\
\hline \multirow[t]{3}{*}{ Eff } & Pearson Correlation & .352 & .227 & $.759^{* *}$ & $.911^{* *}$ & $.942^{* *}$ & $.781^{* *}$ & 1 \\
\hline & Sig. ( P value) & .198 & .528 & .002 & .000 & .000 & .005 & \\
\hline & $\mathrm{N}$ & 15 & 10 & 14 & 12 & 11 & 11 & 16 \\
\hline
\end{tabular}

Table 9: COD correlations between drawers for all experiments.

\begin{tabular}{llrrrrrrr}
\hline & \multicolumn{9}{c}{ Correlations } \\
\hline & \multicolumn{1}{c}{ Inf. } & \multicolumn{1}{c}{ D1 } & \multicolumn{1}{c}{ D2 } & \multicolumn{1}{c}{ D3 } & \multicolumn{1}{c}{ D4 } & \multicolumn{1}{c}{ D5 } & \multicolumn{1}{c}{ Eff. } \\
\hline Inf. & Pearson Correlation & 1 & -.151 & .187 & .005 & .231 & .176 & .042 \\
& Sig. (P value) & & .746 & .688 & .991 & .709 & .739 & .921 \\
& $\mathrm{~N}$ & 10 & 7 & 7 & 7 & 5 & 6 & 8 \\
D1 & Pearson Correlation & -.151 & 1 & -.617 & -.204 & -.635 & -.335 & -.613 \\
& Sig. ( P value) & .746 & & .267 & .698 & .365 & .665 & .272 \\
& $\mathrm{~N}$ & 7 & 7 & 5 & 6 & 4 & 4 & 5 \\
D2 & Pearson Correlation & .187 & -.617 & 1 & $.880^{* * *}$ & $.921^{* * *}$ & $.901^{*}$ & $.903^{* *}$ \\
& Sig. (P value) & .688 & .267 & & .009 & .009 & .014 & .002 \\
& N & 7 & 5 & 8 & 7 & 6 & 6 & 8 \\
D3 & Pearson Correlation & .005 & -.204 & $.880^{* * *}$ & 1 & $.952^{* * *}$ & .760 & $.965^{* * *}$ \\
& Sig. (P value) & .991 & .698 & .009 & & .003 & .136 & .000 \\
& $\mathrm{~N}$ & 7 & 6 & 7 & 8 & 6 & 5 & 7 \\
\hline
\end{tabular}




\begin{tabular}{llrrrrrrr}
\hline D4 & Pearson Correlation & .231 & -.635 & $.921^{* *}$ & $.952^{* *}$ & 1 & $.905^{* *}$ & $.991^{* *}$ \\
& Sig. ( P value) & .709 & .365 & .009 & .003 & & .035 & .000 \\
& N & 5 & 4 & 6 & 6 & 6 & 5 & 6 \\
D5 & Pearson Correlation & .176 & -.335 & $.901^{*}$ & .760 & $.905^{*}$ & 1 & $.853^{*}$ \\
& Sig. ( P value) & .739 & .665 & .014 & .136 & .035 & & .031 \\
& N & 6 & 4 & 6 & 5 & 5 & 6 & 6 \\
Eff & Pearson Correlation & .042 & -.613 & $.903^{* *}$ & $.965^{* *}$ & $.991^{* *}$ & $.853^{*}$ & 1 \\
& Sig. ( P value) & .921 & .272 & .002 & .000 & .000 & .031 & \\
& N & 8 & 5 & 8 & 7 & 6 & 6 & 10 \\
$* *$ Correlation is significant at the 0.01 level. & & & & & & \\
$*$ Correlation is significant at the 0.05 level. & & & & & & & \\
\hline
\end{tabular}

\subsubsection{Filtered vs. Total $\mathrm{BOD}_{5}$}

Filtered $\mathrm{BOD}_{5}\left(\mathrm{fBOD}_{5}\right)$ refers to the amount of dissolved food available for microorganisms in the water being treated (Metcalf \& Eddy, 1991). It is tested in the water that has been filtered in the standard total suspended solids test. Subtraction of filtered $\mathrm{BOD}_{5}$ from total $\mathrm{BOD}_{5}\left(\mathrm{tBOD}_{5}\right)$ will give suspended $\mathrm{BOD}_{5}\left(\mathrm{sBOD}_{5}\right)$. Table 10 shows the $\mathrm{fBOD}_{5} / \mathrm{tBOD}_{5}$ ratio for all experiments (Standard method, 1995).

Table 10: $\mathrm{fBOD}_{5} / \mathrm{tBOD}_{5}$ ratio for the influent synthetic greywater for all loads.

\begin{tabular}{lllll}
\hline $\begin{array}{l}\text { Experiment } \\
\text { number }\end{array}$ & $\mathrm{fBOD}_{5} \mathrm{mg} / \mathrm{l}$ & $\mathrm{tBOD}_{5} \mathrm{mg} / \mathrm{l}$ & $\mathrm{fBOD}_{5} / \mathrm{HOD}_{5}$ & Notes \\
\hline 1 & 69 & 125 & 0.56 & $\begin{array}{l}44 \% \text { of organic compounds are } \\
\text { suspended and the rest are soluble. }\end{array}$ \\
2 & 63 & 169 & 0.37 & $\begin{array}{l}63 \% \text { of organic compounds are } \\
\text { suspended and the rest are soluble. }\end{array}$ \\
3 & 69 & 207 & 0.33 & $\begin{array}{l}67 \% \text { of organic compounds are } \\
\text { suspended and the rest are soluble. }\end{array}$
\end{tabular}

Looking at table (10) in conjunction with Figure (3- a, b \& c), one can conclude that drawer number one had been working more effectively during the experiments 2 and 3, than it was working during experiment 1 , i.e. $60 \%$ of $\mathrm{BOD}_{5}$ removal occurred in this drawer during experiments $2 \& 3$, whereas about $30 \%$ of $\mathrm{BOD}_{5}$ removal was achieved by the same drawer in experiment 1 , which is essentially related to $\mathrm{fBOD}_{5} / \mathrm{tBOD}_{5}$ ratio. This is, however, quite similar to what was demonstrated by Dalahmeh et al. 2011; Assayed et al. 2010; Halalshe et al. 2007, who found that when wastewater has high $\mathrm{SBOD}_{5}$ then physical pre-treatment is required to improve the quality of greywater being treated. 


\subsection{Sand hydraulic conductivity (permeability)}

Sand hydraulic conductivity is closely related to the organic and hydraulic loading being used (Roadgers et al. 2004, Beach et al. 2006). Sand hydraulic conductivity dramatically decreased when water goes further through the drawers. This was noticed in all experiments at all doses. In the present filter design, restoring some of the sand hydraulic conductivity has been easily achieved by sliding out the drawer and leaving it to rest for 24-48 hours after mixing up the media inside. This implies that the filter at these times would have been working without one of the drawer which might have impacts on the overall performance, which was not tackled during this research. However, spare drawers could be added to the system and used alternatively with clogged drawers if needed. This was in consistent with Torrens et al. 2009, Leverenze et al. 2009 who found that giving rest periods for 3-7 days could be efficient to improve permeability and restore some of hydraulic conductivity of sand.

\subsection{General discussion}

The results of the laboratory trials showed that DCSF was suitable for greywater treatment with high efficiency and minimal maintenance requirements. The oxidation of organic matter for all tested doses (represented by $\mathrm{BOD}_{5}$ and $\mathrm{COD}$ ) was found to be more than $90 \%$, assuring the availability of oxygen for organic matter degradation. The majority of organic matter oxidation $(\simeq 90 \%)$ in all dose trials was achieved after water passed through the drawer number three. This was consistent with Levernze et al. 2009, Torrens et al. 2009 and Rodgers et al. 2004 who found that the aerobic oxidation of organic matter in sand filtration mainly occurs on the upper surface of sand where oxygen is available in enough quantities to oxidize most of organic matters. In DCSF, the sand is placed in movable drawers with only $10 \mathrm{~cm}$ depth and is exposed to air from above and below; this facilitated oxygen movement within and between the sand layers, thus oxidation occurs in all layers with no chance of oxygen depletion. This compares to conventional intermittent sand filters where 60 to $90 \mathrm{~cm}$ is bulked in one single bed, either under or above ground, and thus causes anaerobic conditions in the lower parts which in most cases leads to unpleasant odors and poor performance (Assayed et al. 2010).

DCSF was tested and operated under high hydraulic and organic load conditions. According to Metcalf \& Eddy (1991), the maximum hydraulic and organic load for an intermittent sand filter is $40 \mathrm{~L} / \mathrm{m}^{2} \cdot \mathrm{d}^{-1}$ and $9 \mathrm{gBOD} 5 / \mathrm{m}^{2} \cdot \mathrm{d}^{-1}$, respectively. The DCSF was tested in this research 
with a hydraulic load of $142 \mathrm{~L} / \mathrm{m}^{2} \cdot \mathrm{d}^{-1}$ and organic load of $30 \mathrm{gBOD} / \mathrm{m}^{2} \cdot \mathrm{d}^{-1}$, thus exceeding the Metcalf \& Eddy design guidelines by 3.5 times for the hydraulic load and 3.3 times for the organic load. This high hydraulic and organic load, according to Leverenz et al. (2009), would substantially increase the clogging incidences and the overall filter failure. However, clogging was not experienced in the DCSF with any of the doses regimes. This was attributed to the concept of movable drawers, which allowed the user to slide out the sand layer and mix up the media then leave it to rest for 24-48 hours. This was sufficient to restore the sand media and delay the clogging occurrence and was consistent with Rodgers et al. 2004, Torrens et al. 2009 and Leverenze et al. 2009

Three logs of E.coli reduction were achieved for all hydraulic and organic loads tested. This exceeded the removal of faecal coliforms reported by Jenkins et al. (2011) who applied river water augmented with raw wastewater onto two fine sand size layers $\left(D_{10}=0.17\right.$ and 0.52 $\mathrm{mm})$ placed under three hydraulic heads $(10,20$, and $30 \mathrm{~cm})$. The maximum faecal coliforms removal as reported in the Jenkins et al. (2011) experiment was 1.4 logs. However, effective sand size, pausing time and increase residence time emerged as highly beneficial for improving the removal of pathogens from water when using sand filtration (Stevik et al. 1999; Bauer et al. 2011; Cuyk et al. 2001). The satisfactory performance in terms of of E.coli removal by using DCSF can be understood by looking at the findings of Stevik et al. (1999) who observed that $99 \%$ of E.coli removal takes place in the upper $10 \mathrm{~cm}$ of sand media, which according to Vavai (2010) is attributed to biofilm growth and solids build up on the upper surface, leading to a decrease in the free pore spaces, thus increasing the capability of straining and trapping the bacteria. Given the good aeration in all drawers at all levels in the DCSF, biofilm and solids accumulation occurs on the upper surface for all drawers (as shown in the permeability test); therefore, DCSF, through the concept of drawers, provides several subsequent barriers for bacteria.

Fully aerobic conditions seemed to be dominant in DCSF, as water flowed downward from one drawer to another and did not accumulate in the lower parts of the sand media. Although the dominance of aerobic conditions was not investigated by the laboratory analyses (i.e. measuring the dissolved oxygen, levels of nitrification or concentration of $\mathrm{H}_{2} \mathrm{~S}$ ), no bad smells were noticed emerging from the unit during the whole period of operation. This was in contrast to what has been reported for conventional intermittent sand filters where emission of bad smells have been one of the main shortcomings identified (Assayed et al. 2010). 


\section{Conclusions}

The DCSF was found able to overcome the problems commonly associated with conventional sand filter design, such as clogging and the need for a large land area to house the filter.

Several conclusions can be drawn from this research:

1. No significant difference was noticed in terms of overall filter efficiency between different loads for all parameters. 90-95\% of organic matter removal was achieved for all doses at all loads. A significant reduction in $\mathrm{BOD}_{5}$ and $\mathrm{COD}(\mathrm{P}<0.05)$ was noticed after water drained through the third drawer in all tested loads.

2. The drawer filter with a minimum 3 drawers and $75 \mathrm{~cm}^{*} 75 \mathrm{~cm} * 14 \mathrm{~cm}$ dimension for each drawer is sufficient for efficiently treating up to $80 \mathrm{~L} /$ day and $\leq 210 \mathrm{mg} / \mathrm{l}$ of $\mathrm{BOD}_{5}$ with minimal maintenance requirements. Sliding the drawer out and mixing up the media inside is sufficient to restore the filtering media and delay clogging occurrence.

3. Intermittent sand filters could be designed in a rather different way to what is mentioned in Metcalf \& Eddy and EPA guidelines. The essence of the new suggested design is placing filtering media in movable drawers rather than bulking out the media in underground excavation.

4. This new compact design would allow sand filters to be used in locations where space is at a premium, such as dense urban areas, and the low maintenance requirements mean that a wide range of users could easily operate a DCSF.

5. This research article provides preliminary perspective on DCSF. Further investigation is required to cover several aspects of this new filter design such as: responses to different hydraulic and organic loads, the performance when using different media with different sizes, using different drawers' dimensions, the impacts of this new design on the mechanism of bacterial removal, responses to different media depth and finding out the mechanism of water movement through each drawer by using chemical tracers. 


\section{Acknowledgment}

Authors would like to thank the people of Royal Scientific Society (RSS), particularly the staff of environmental labs for their unlimited support. Special thank goes to Mrs Mervat Kamel from the microbiology unit in RSS for her kind assistance in coliforms analysis.

\section{References}

Abdel-Kader A. (2013) 'Studying the efficiency of greywater treatment by using rotating biological contactors system', Journal of King Saud University-Engineering Sciences (25) pp. 89-95.

Abu Ghunmi L., Zeeman G., Van Lier J., and Fayyed M. (2008) 'Quantitative and qualitative characteristics of greywater for reuse requirements and treatment alternatives: the case of Jordan', Water Science \& Technology (58.7), pp. 1385-1396.

Abu Ghunmi L., Zeeman G., Van Lier J., and Fayyed M. (2011) 'Greywater treatment systems: a review', Critical reviews in Environmental Science and Technology (41) pp. 657698.

Al-Jamrah A., Ayyash S. (2008). 'Greywater generation and characterization in major cities in Jordan', Jordan Journal of Civil Engineering. Volume 2, No.4.

Ammary B. (2007). Wastewater reuse in Jordan: Present status and future plans. Desalination (211) pp 164-176.

APHA. (1995). Standard methods for the examination of water and wastewater (19th ed.). Washington: American Public Health Association.

Assayed A., Dalahmeh S., Suleiman W. (2010) 'Onsite Greywater Treatment Using Septic Tank Followed by Intermittent Sand Filter- A Case Study of Abu Al Farth Village in Jordan', International Journal of Chemical and Environmental Engineering, Vol. 1 No. 1.

Bauer R., Dizer H., Graeber I., Rosenwinkel K-H. (2011) 'Removal of bacterial fecal indicators, coliphages and enteric adenoviruses from waters with high fecal pollution by slow sand filtration', Water Research (45) pp. 439-452. 
Beach D., McCray J., Lowe K., Siegrist R. (2005). Temporal changes in hydraulic conductivity of sand porous media biofitlers during wastewater infiltration due to biomat formation', Journal of Hydrology (311), pp $230-243$.

Boufaroua M., Albalawneh A., Oweis T. (2013) 'Assessing the Efficiency of Grey-Water Reuse at Household Level and Its Suitability for Sustainable Rural and Human Development', British Journal of Applied Science \& Technology (3) pp. 962-972.

Chris B. and Martin K. 2009. Basic water treatment, $4^{\text {th }}$ edition. Published by Thomas Telford, London, UK.

Cuyk S.V., Siegrist R., Logan A., Masson S., Fischer E., Figueroa L. (2001) 'Hydraulic and purification behaviours and their interactions during wastewater treatment in soil infiltration systems', Wat. Res. (35) pp. 953-964.

Dalahmeh S., Hylander L., Oborn I., Pell M., Oborn I., Jonsson H. (2011) 'Potential of organic filter materials for treating greywater to achieve irrigation quality: a review', Water science and technology, 1832-1840.

Dalahmeh S., Pell M., Vinneras B., Hylander L., Oborn I., Jonsson H. (2012) 'Efficiency of bark, activated charcoal, foam and sand filters in reducing pollutants from greywater', water air soil pollution (012).

Dallas S., Scheffe B., Ho G. (2004) 'Reedbeds for greywater treatment- a case study in Sant Elena-Monteverde, Costa Rica , Central America', Ecological Engineering (23) pp. 55-61.

Domenech L., Sauri D. (2010) 'Socio-technical transitions in water scarcity contexts: public acceptance of greywater reuse technologies in the Metropolitan Area of Barcelona', Resources, Conservation and Recycling (55) pp. 53-62.

Elmitwalli TA. and Otterpohl R. (2007) 'Anaerobic biodegradability and treatment of grey water in upflow anaerobic sludge blanket (UASB) reactor', Water Res (41) pp.1379-87

Eriksson E., Auffarth K., Henze M., Ledin A. (2002) 'Characteristics of grey wastewater, Urban water (4), pp. 85-104. 
Ghaitiadak D. and Yadav K. (2013). 'Characteristics and treatment of greywater - a review”, 'Enviorn Sci Pollut Res (20) pp. 2795-2809.

Halalsheh, M., Dalahmeh, S., Sayed, M., Suleiman,W., Shareef,M., Mansour, M., \& Safi, M. (2008).

'Grey water characteristics and treatment options for rural areas in Jordan', Bioresource

Technology, 99, 6635-6641.

Jefferson, B., Palmer, A., Jeffrey, P., Stuetz, R., Judd, S., 2004. Grey water characterisation and its impact on the selection and operation of technologies for urban reuse. Water Sci. Technol. 50 (2), $157-164$

Kraume M., Scheumann R., Baban A. and El Hamouri B. (2010) 'Performance of a compact submerged membrane sequencing batch reactor for greywater treatment', Desalination (250) pp. 1011-1013.

Lamine M., Bousslemi L., and Ghrabi A. (2007) 'Biological treatment of greywater using sequencing batch reactor', Desalination (215) pp. 127-132.

Leal H., Temmink H., Zeeman G., Buisman C. (2011) 'Characterization and anaerobic biodegradability of greywater', Desalination (270) pp. 111-115.

Leverenze G., Tchobanoglous G., and Darby J. (2009) 'Clogging in intermittently dosed sand filters used for wastewater treatment', Water Research (43), pp. 695-705.

Lin C-J., Lo S-L., Kuo C-Y., Wu C-H. (2005) 'Pilot-scale electrocoagulation with bipolar aluminium electrodes for on-site domestic greywater reuse', J Environ Eng (491).

Metcalf and Eddy (1991) Wastewater Engineering, Treatment and Reuse, $3^{\text {rd }}$, Mc-Graw Hill Inc, New York.

Nolde E. (1999) 'Greywater reuse for toilet flushing in Multi-storey buildings-over ten years experience in Berlin', Urban Water, Vol 1 pp 275-284.

Nolde E. (2005) 'Greywater recycling systems in Germany- results, experiences and guidelines', Water Science \& Technology Vol 51 No 10 pp 203-210.

Palmquist H. and Haneus J. (2005) 'Hazardous substances in separately collected grey and blackwater from ordinary Swedish households', Science of the Total Environment (48) pp. 151-163. 
Pidou M., Avery L., Stephenson T., Jeffery P., Parsons S., Liu S., Memon F., Jefferson B. (2008) 'Chemical solutions for greywater recycling', Chemosphere (71) pp. 147-155.

Rodgers M., Mulqueen J., and Healy M.G. (2004) 'Surface clogging in an intermittent stratified sand filter', Soil Science Society of America Journal (68), pp. 1827-1832.

Seigrist R.L. (1987) 'Soil clogging during subsurface wastewater infiltration as affected by effluent composition and loading rate', Journal of Environmental Quality, 16(2), pp 181-187.

Stevik T., Ausland G., Jenssen P., Siegrist R. (1999). 'Removal of e.coli during intermittent sand filtration of wastewater as affected by dosing rate and media depth', water research Vol. 33. No. 9. PP. 2088-2098.

Torrens A., Molle P., Boutin C. and Salgot M. (2009) 'Impact of design and operation variables on the performance of vertical-flow constructed wetlands and intermittent sand filters treating pond effluent', Water Research (43), pp. 1851-1858.

Tyagi V., Khan A., Kazmi A., Mehrotra I., Chopra A. (2009). 'Slow sand filtration of UASB reactor effluent: A promising post treatment technique', Desalination (249) pp 571-576.

U.S Environmental Protection Agency USEPA (2002) On-site wastewater treatment systems manual. EPA/625/R-00/008.

Vavai K. Porous media: application in biological systems and biotechnology, eBook , Published by: Taylor \& Francis 2011.

Winward G., Avery L., Frazer-Williams R., Pidou M., Jeffrey P., Stephenson T., and Jefferson B. (2008) 'A study of the microbial quality of greywater and an evaluation of treatment technologies for reuse', Ecological Engineering (32) pp 187-197. 